\title{
EFFECT OF ZINC SUPPLEMENTION FROM INORGANIC AND ORGANIC SOURCES ON NUTRIENT DIGESTIBILITY, SOME BLOOD METABOLITES AND GROWTH PERFORMANCE OF GROWING BUFFALO CALVES
}

\author{
E. H. Hassan ${ }^{1}$; M.M. Farghaly ${ }^{2}$ and G.M. Solouma ${ }^{3}$ \\ ${ }^{1}$ Animal Production Department, Faculty of Agriculture, Al-Azhar University Assiut, Egypt \\ ${ }^{2}$ Animal Production Department, Faculty of Agriculture, Assiut University, Egypt \\ ${ }^{3}$ Animal Production Department, Faculty of Agriculture, Sohag University, Egypt
}

(Received 29/11/2015, accepted 16/2/2016)

\section{SUMMARY}

$\mathrm{T}$

This study was conducted to determine the effects of zinc supplementation either from inorganic or organic sources on digestibility, blood metabolites and animal performance. Twelve buffalo calves of 11-13 months of age weighing $257.66 \pm 26.41 \mathrm{~kg}$ were divided into three similar groups of 4 calves each, where G1 was served as control ration, and was fed the basal diet consisting of roughage and concentrate mixture. While the two tested groups were fed the same basal diet, but supplemented with 30 mg $\mathrm{Zn} / /$ head/day of $\mathrm{Zn}$ sulphate (G2). And supplemented with $30 \mathrm{mg} \mathrm{Zn//head/day} \mathrm{as} \mathrm{Zink} \mathrm{methionine} \mathrm{(} \mathrm{G3).}$ The basal diet contains $28.3 \mathrm{mg} / \mathrm{kg} \mathrm{Zn}$, and, additionally, the doses of $\mathrm{Zn}$ in the tested groups were orally supplemented. All animals of these groups were fed $80 \%$ of their requirements as concentrate mixture and the rest of requirements were covered from wheat straw and alfalfa hay in equal quantities . The daily requirements of energy and crude protein for growing calves were cover according (NRC, 2001). Results indicated that supplemented $\mathrm{Zn}$ methionine or $\mathrm{Zn}$ sulphate to calves diet increased significantly $(\mathrm{p}<0.05)$ all nutrient digestibilities and feeding value in terms of TDN and DCP as compared with control group. Also, Supplemented Zn methionine for calves' diet increased significantly $(\mathrm{p}<0.05)$ the consenterion of serum $\mathrm{Zn}$, plasma T3 and decreased significantly $(\mathrm{p}<0.05)$ cholesterol concentration as compared with $\mathrm{Zn}$ sulphate and control groups. While, serum total protein, Albumin, globulin, and AST were not affected significantly by zinc supplementation from inorganic or organic sources in buffalos calves in comparison with control ration. The body weight and daily gain were significantly higher $(\mathrm{P}<0.05)$ for claves fed supplemented $\mathrm{Zn}$-methionine or zinc sulphate ration, than those fed control one. The body weight gain in Zn-methionine group was increased by about $35.29 \%$ and $16.59 \%$ than those fed control or zinc sulphate ration, respectively. There was no significant difference in total feed intake among different groups. Supplementation of $\mathrm{Zn}$-meth significantly $(\mathrm{P}<0.05)$ improved the feed conversion efficiency and the feed cost/kg weight gain as compared with $\mathrm{Zn}$ sulphate and control groups.

From the results of this study it could be concluded that supplemented zinc from inorganic or organic sources in buffalo's calves diets improved digestibility and performances of growing buffalo and calves could be recommended that supplement Zn-methionine to growing buffaloes calves rations under Upper Egypt conditions because of its higher bioavailability than $\mathrm{Zn}$ sulphate.

Keywords: growing buffalo calves, Zn-methionine, Zn sulphate, performance, blood metabolites, nutrient digestibility, feeding value

\section{INTRODUCTION}

Zinc is essential for both human beings and animals and plays significant role in different enzymatic systems needed in nucleic acid metabolism, protein synthesis and carbohydrate metabolism (Chester, 1997). Zinc also may play important roles in thyroid metabolism. Thus, its low (Gupta et al., 1997; Ruz et al., 1999) or excessive (Dean et al., 1991) levels may cause numerous abnormalities , . of metabolic processes .Therefore, it has been emphasized that excessive dietary zinc intake resulted in disturbances in serum thyroid hormone levels in human (Miyamoto et al.,1991) and animals (Dean et al., 1991). Excess zinc has been found to decrease the levels of serum thyroxine $\left(\mathrm{T}_{4}\right)$ and triiodothyronine $\left(\mathrm{T}_{3}\right)$ in poultry (Dean et al., 1991) and in humans (Nishiyama et al., 1994). 


\section{Hassan et al.}

Marginal deficiency of zinc in ruminants has been reported in many parts of the tropical countries including different geological regions or most growing plants in Egypt (El-Fouly et al., 1984) and thus needs supplementation in the diets of livestock (McDowell, 1992). Also, Corah and Dargatz (1996) reported that $97.5 \%$ of forages analyzed were stated in range from deficient to marginal in $\mathrm{Zn}$ in this respect, some reports recorded that the minimum zinc level of the diet must be $20-33 \mathrm{mg} \mathrm{Zn} / \mathrm{kg}$ diet in ruminants (National Research Council, 1985 and McDowell, 1992). The Beef Cattle National Research Council (NRC, 2000) recommends that beef cattle feedlot diets contain $30 \mathrm{mg} \mathrm{Zn/kg} \mathrm{DM,} \mathrm{despite} \mathrm{a}$ survey of consulting feedlot nutritionist indicated that feedlot diets are formulated to contain, on average, 93 ppm Zn with a range of 40 - 213 ppm (Vasconcelos and Galyean, 2007). On the other hand, National Research Council, (1984) reported that Zn concentrations of $500 \mathrm{mg} / \mathrm{kg}$ of diet will cause toxicity in beef cattle, however most livestock species tolerate concentrations as high as $1000 \mathrm{mg} / \mathrm{kg}$ in the diet (McDowell, 1992). Spears and Kegley (2002) have reported an improvement in the growth rate of calves on supplementation of $25 \mathrm{mg} \mathrm{Zn/kg} \mathrm{DM,} \mathrm{over} \mathrm{a} \mathrm{basal} \mathrm{diet} \mathrm{that} \mathrm{contend} 33 \mathrm{mg} \mathrm{Zn/kg} \mathrm{DM}$.

Traditionally, the major sources of $\mathrm{Zn}$ amongst the mineral supplements for animal feeding have been its inorganic salts like $\mathrm{Zn}$ sulphate $\left(\mathrm{ZnSO}_{4}\right), \mathrm{Zn}$ oxide $(\mathrm{ZnO}), \mathrm{Zn}$ chloride $\left(\mathrm{ZnCl}_{2}\right)$, etc. However, recent studies showed that $\mathrm{Zn}$ supplementation through mineral proteinases or mineral amino acid chelates as organic sources which effectively had higher retention (Lardy et al., 1992), more bioavailability (Spears, 1989) and tissue concentrations (Cao et al., 2000) relative to inorganic sources The beneficial effects of chelation on mineral metabolism is well established. It is the safest and most natural conveyance for getting needed metal elements in the living system of the animal. It is a relatively new concept to create mineral chelates in bio- compatible and bio- available forms that are transported to and utilized to the needed metabolic sites. Hempe and Cousins (1989) reported that Zn-methionine complex is transported intact from the intestinal lumen into mucosal cells, increasing tissue supply of $\mathrm{Zn}$ and thereby improving animal productivity. Also, Power et al. (1994) showed that the bioavailability of zinc proteinate to be $159 \%$ of the bioavailability of zinc sulfate in rats.

The objective of this research was to evaluate the effect of the supplementation of zinc sulphate and zinc $\mathrm{Zn}$-methionine as sources of supplemental $\mathrm{Zn}$ in the diet on growth performance, nutrient digestibility, and blood metabolites of growing buffalo calves.

\section{MATERIALS AND METHODS}

\section{Animals, rations and management}

The experiment was carried out at the research farm of Faculty of Agriculture, Al-Azhar University, Assiut branch, Egypt. Twelve healthy buffalo calves of 13-14 months of age weighing $257.66 \pm 26.41 \mathrm{~kg}$ were divided into three groups of ( 4 animals each) on the basis of their average live body weight. Group 1 was kept as a control and fed a basal diet consisting of roughage and concentrate feed mixture(CFM). Group 2 fed the basal diet supplemented with $30 \mathrm{mg} \mathrm{Zn//head/day} \mathrm{as} \mathrm{Zn} \mathrm{sulphate} \mathrm{(Zn} \mathrm{So4),} \mathrm{while} \mathrm{Group} 3$ received the same basal diet that supplemented with $30 \mathrm{mg} \mathrm{Zn//head/day} \mathrm{as} \mathrm{Zn-methionine(Zn-meth).}$ The basal diet contains $28.3 \mathrm{mg} / \mathrm{kg}$ (DM basis). Zn, additionally, the doses of $\mathrm{zn}$ in the tested rations were orally supplemented. The source of zinc-methionine is Sulfozyme Agro Pvt. Ltd., India and the source of $\mathrm{Zn}$ sulphate is from the Egyptian market. Concentrate feed mixture contained $51 \%$ corn grains, $20 \%$ Corticated cotton seed meal, $25 \%$ wheat bran, $1 \%$ mineral mixture (without $\mathrm{Zn}$ ), $2 \%$ limestone and common salt $1 \%$.

The animal's requirements for CP and TDN were calculated according to NRC (2001). Where the concentrate to roughage ratio was 80:20, respectively based on DMand the roughage portion consisted of wheat straw and alfalfa hay and they were given in equal amount in each animal group all groups were fed $80 \%$ of their requirements as concentrate. The quantity of concentrate mixture was adjusted every month according to change in body weight (NRC, 2001). The animals were randomly allotted to experimental diets.

The ingredients and chemical composition of experimental diet are shown in Table (1). Rations were offered twice a day and the feed orts were weighed daily through the experimental period and actual feed intake was calculated. Feed conversion ratio was calculated and expressed in terms of kg dry matter (DM per one-kg body weight gain. Diets were mixed daily and fed twice a day. All the experimental animals were housed in a well-ventilated animal shed with cemented floor and provision of individual feeding and watering. The calves were weighed at the start of the feeding trial and then every month to determine changes in the body weight (BW), before marling feeding and drinking. Economic analysis of data was 
done using the technique of Perrin et al. (1979). Clean drinking water with no detectable amounts of $\mathrm{Zn}$ was provided ad libitum twice (at 10 and $15 \mathrm{~h}$ ). After 30 days of adaptation, calves were fed their respective treatment diets for a period of 120 days.

Table (1): Ingredients composition (g/kg DM) and chemical composition of concentrate mixture

\begin{tabular}{lc}
\hline Ingredients composition & $\%$ \\
\hline Corn & 51 \\
Wheat bran & 25 \\
Corticated cotton seed meal & 20 \\
Limestone & 2 \\
Salt & 1 \\
Minerals Mixture & 1 \\
Total & 100 \\
Ash & 6.79 \\
Zn/mg/kg DM & 28.3 \\
\hline
\end{tabular}

\section{Digestibility trials}

Digestibility trials were conducted to determine the digestion coefficients for the three different experimental diets. Each digestibility trial was carried out using three buffalos. Calves and lasted for 12day where the first 5-day was considered as a preliminary period followed by a 7-day collection period.

The rations were sampled daily during the trial and the samples were composited at the end of each trial, ground through $1 \mathrm{ml}$. screen, and stored for chemical analysis. Faeces were weighed just at the time of collection and $10 \%$ of the total amount were taken and dried at $60-70{ }^{\circ} \mathrm{C}$ for $24 \mathrm{~h}$. The dried samples were mixed and ground for chemical analysis. The daily dried fecal samples from each animal were grounded through $1 \mathrm{~mm}$ mill screen and saved for chemical analysis.

\section{Chemical analysis and digestion coefficients measurements:}

The chemical analysis of feeds and faeces were carried out according to the procedures of Association of Official Analytical Chemists (AOAC, 2000) using duplicate samples. The apparent digestion coefficients of nutrients were calculated by expressing the difference between the content of nutrient in both consumed feed and faeces as a percentage of its intake.

\section{Blood sampling:}

Blood samples were collected from the jugular vein monthly after the morning feeding. Blood samples were immediately centrifuged at $3000 \mathrm{rpm}$ for $20 \mathrm{~min}$. and serum was stored at $-20{ }^{\circ} \mathrm{C}$ until analysis. Concentration of Serum total protein (TP) albumin (AL), ALT, AST and cholesterol were determined by spectrophotometer (Unico, USA) using commercial test kits (Spinreact, Spain). Serum globulin (GL) was obtained as the difference between the TP and AL concentrations. Concentration of zinc in serum was estimated in an air-acetylene flame using atomic absorption spectrophotometer (Model 5100, HGA- 600 Graphite Furnace; PerkinElmer, USA). Estimation of triiodothyronine (T3) and thyroxin (T4) in blood plasma samples was done by radioimmunoassay technique using an automatic gamma counter (Packard, USA, Model Cobra II) by the method suggested by Bhandarkar and Pillai (1982).

\section{Statistical analysis}

Statistical analysis was carried out using general linear model (G.L.M) of S.A.S (2001) program, version 8.2. Differences between groups in nutrient digestibility, blood metabolites and performance data were evaluated by one way ANOVA. The significance differences between treatments means were tested by Duncan Multiple Range Test (Steel and Torrie, 1980). The data were presented in mean \pm S.E.M and the level of significance was set at $\mathrm{P}<0.05$. 


\section{Hassan et al.}

\section{RESULTS AND DISCUSSION}

\section{Nutrients digestibility}

The values of nutrient digestibility of the experimental rations are presented in (Table 2). Results of digestibility trials showed that supplemented $\mathrm{Zn}$ sulphate or $\mathrm{Zn}$ methionine to the tested rations (G2\& G3) increased significantly $(\mathrm{p}<0.05)$ all nutrients digestibility as compared with control groups.(G1), also, digestibility of most nutrients of zn-meth ration were significant higher than those of zn so4-ration. Similar results were confirmed by Salama Ahmed et al. (2003) who reported that increased digestibility of DM, OM and CP in dairy goats supplemented with $1 \mathrm{~g} /$ day Zn-methionine in their diet. Garg et al. (2008) found that supplementation of a diet containing originally $34 \mathrm{mg} \mathrm{Zn} / \mathrm{kg} \mathrm{DM}$, with $20 \mathrm{mg}$ of organic $\mathrm{Zn} / \mathrm{kg} \mathrm{DM}$ improved significantly $(\mathrm{P}<0.05)$ ADF and cellulose digestibility in lambs, but DM, CP and NDF digestibilities were not affected, suggesting a positive role of organic $\mathrm{Zn}$ supplementation in fibre degradation. In contrast, Mandal et al. (2007) indicated that DM, CP, ADF and NDF digestibility were not affected by dietary $\mathrm{Zn}$ in bulls fed a basal diet $(32.5 \mathrm{mg} \mathrm{Zn} / \mathrm{kg} \mathrm{DM})$ as it supplemented with $35 \mathrm{mg}$ $\mathrm{Zn} / \mathrm{kg}$ DM. Also, Wenbin et al. (2008) found that digestibility of DM, CP, (NDF) and (ADF) did not differ $(P>0.05)$ among treatments groups that supplemented with 30 and $45 \mathrm{mg} \mathrm{Zn} / \mathrm{kg}$ DM for goats.

Table (2): Effect of source of zinc on nutrient apparent digestibility and feeding value \%.

\begin{tabular}{lcccc}
\hline Items & $\begin{array}{c}\text { Control } \\
(\mathrm{G} 1)\end{array}$ & $\begin{array}{c}\text { ZnSO4 } \\
(\mathrm{G} 2)\end{array}$ & $\begin{array}{c}\text { Zn-meth } \\
(\mathrm{G} 3)\end{array}$ & $\mathrm{P}$ \\
\hline $\mathrm{DM}$ & $54.28^{\mathrm{c}} \pm 0.96$ & $64.68^{\mathrm{b}} \pm 0.16$ & $74.81^{\mathrm{a}} \pm 0.27$ & 0.0001 \\
$\mathrm{OM}$ & $57.64^{\mathrm{c}} \pm 0.79$ & $67.46^{\mathrm{b}} \pm 0.12$ & $76.40^{\mathrm{a}} \pm 0.26$ & 0.0001 \\
$\mathrm{CP}$ & $73.36^{\mathrm{c}} \pm 0.79$ & $79.04^{\mathrm{b}} \pm 0.57$ & $86.45^{\mathrm{a}} \pm 0.40$ & 0.0001 \\
$\mathrm{CF}$ & $40.80^{\mathrm{c}} \pm 1.38$ & $55.55^{\mathrm{b}} \pm 1.20$ & $70.36^{\mathrm{a}} \pm 0.75$ & 0.0001 \\
$\mathrm{EE}$ & $86.38^{\mathrm{b}} \pm 2.07$ & $93.48^{\mathrm{a}} \pm 0.59$ & $93.68^{\mathrm{a}} \pm 1.25$ & 0.0018 \\
$\mathrm{NFE}$ & $56.91^{\mathrm{c}} \pm 1.16$ & $67.39^{\mathrm{b}} \pm 0.36$ & $75.24^{\mathrm{a}} \pm 0.37$ & 0.0001 \\
TDN, \% & $58.52^{\mathrm{c}} \pm 1.56$ & $67.96^{\mathrm{b}} \pm 1.20$ & $74.05^{\mathrm{a}} \pm 0.61$ & 0.0001 \\
DCP & $8.38^{\mathrm{c}} \pm 0.12$ & $9.33^{\mathrm{b}} \pm 0.07$ & $9.66^{\mathrm{a}} \pm 0.09$ & 0.0001 \\
\hline
\end{tabular}

Means within row bearing different superscripts differ significantly $(p<0.05)$.

ZnSO4: Zn sulphate (added $\mathrm{Zn}=30 \mathrm{mg} / \mathrm{head} /$ day).

Zn-meth: Zn-methionine (added $\mathrm{Zn}=30 \mathrm{mg} /$ head/day)

The feeding value in terms of total digestible nutrients (TDN), was significant higher for calves fed diets with $\mathrm{Zn}$ methionine or $\mathrm{Zn}$ sulphate than that fed the control diet. Also the TDNvalue for zn-meth ration was significantly higher than that of znso4- ration. The improvement in the feeding value of calves fed $\mathrm{Zn}$ methionine or $\mathrm{Zn}$ sulphate than that of control may be due to the higher values of nutrient digestibility ( Table2 ).

\section{Blood metabolites}

The data in Table (3) revealed that there were no significant effects $(\mathrm{P}>0.05)$ in concentrations of serum total protein, Albumin, and globulin due to the two Zn source supplements for calves, based on control ration. The average value of ALT in blood serum of calves fed diet supplemented with Znmethionine was higher $(\mathrm{P}<0.05)$ than those fed diet supplemented with Zn-sulphate (30.77 vs. 25 Unit/1). However, no significant differences were observed among groups for AST. These results are in contrast with those reported by Shinde et al (2013) who found that ALT activities significantly $(\mathrm{p}<0.05)$ declined in $\mathrm{Cu}$ - and $\mathrm{Zn}$-met group than $\mathrm{Cu}$ - and $\mathrm{Zn}$ sulphate indicating an effective role of chelated minerals in improving liver function. Daghash and Mousa (1999) observed higher ALT and AST activity in buffalo calves supplemented with 50 or $100 \mathrm{ppm} \mathrm{Zn.}$

The average value of cholesterol for calves fed diets supplemented with $\mathrm{Zn}$-methionine or $\mathrm{Zn}$-sulphate were significantly lower than those fed control (196.96 and 209.61 vs. 230.47) respectively. From these results it could be noticed that there are inverse relationships between thyroxin level and cholesterol level. This agrees with the statement of Guyton et al. (1991) and Guyton et al. (2000) who mentioned that the increase in the basal metabolic rate (high thyroxin level) is accompanied by a drop of the plasma total cholesterol level. Mirosław et al (2007) reported that enrichment of diet with Se, Zn and vitamin E (0.42, 
68 and $60 \mathrm{mg} / \mathrm{lamb} / \mathrm{day}$, respectively) significantly decreased the cholesterol content of loin muscle and the level of total cholesterol of blood plasma with simultaneously lower HDL level

Table (3): Effect of source of zinc on blood metabolites

\begin{tabular}{lcccc}
\hline Item & $\begin{array}{c}\text { Control } \\
(\mathrm{G} 1)\end{array}$ & $\begin{array}{c}\text { ZnSO4 } \\
(\mathrm{G} 2)\end{array}$ & $\begin{array}{c}\text { Zn-meth } \\
(\mathrm{G} 3)\end{array}$ & $\mathrm{P}$ \\
\hline Total protein (g/dl) & $7.41 \pm 0.18$ & $7.31 \pm 0.09$ & $7.36 \pm 0.23$ & 0.854 \\
Albumin (g/dl) & $4.55 \pm 0.07$ & $4.52 \pm 0.02$ & $4.51 \pm 0.02$ & 0.776 \\
Globulin (g/ dl) & $2.86 \pm 0.21$ & $2.79 \pm 0.09$ & $2.85 \pm 0.22$ & 0.164 \\
A/G ratio & $1.60 \pm 0.19$ & $1.63 \pm 0.06$ & $1.90 \pm 0.43$ & 0.289 \\
ALT (U/l) & $30.00^{\mathrm{a}} \pm 1.90$ & $25.00^{\mathrm{b}} \pm 0.94$ & $30.77^{\mathrm{a}} \pm 1.38$ & 0.020 \\
AST (U/l) & $17.55 \pm 2.25$ & $17.11 \pm 1.94$ & $19.77 \pm 2.11$ & 0.635 \\
Cholesterol mg/dl & $230.47^{\mathrm{a}} \pm 8.49$ & $209.61^{\mathrm{b}} \pm 7.01$ & $196.96^{\mathrm{b}} \pm 4.51$ & 0.007 \\
Zinc, mg 1 & $1.33^{\mathrm{c}} \pm 0.02$ & $1.55^{\mathrm{b}} \pm 0.01$ & $1.62^{\mathrm{a}} \pm 0.01$ & 0.0001 \\
T3, nmol/1 & $1.81^{\mathrm{c}} \pm 0.07$ & $2.13^{\mathrm{b}} \pm 0.04$ & $2.30^{\mathrm{a}} \pm 0.04$ & 0.0001 \\
T4, nmol/1 & $87.89 \pm 3.01$ & $91.22 \pm 3.49$ & $93.22 \pm 6.15$ & 0.695 \\
\hline
\end{tabular}

Means within row bearing different superscripts differ significantly $(p<0.05)$.

ZnSO4: Zn sulphate (added $\mathrm{Zn}=30 \mathrm{mg} /$ head/day).

Zn-meth: Zn-methionine (added $\mathrm{Zn}=30 \mathrm{mg} / \mathrm{head} /$ day).

Results in the present work showed that level of serum $\mathrm{Zn}$ (Table3) was significantly increased $(\mathrm{P}<0.05)$ in $\mathrm{Zn}$-methionine group as compared with Zn-sulphate or control groups. Also, calves fed diet supplemented $\mathrm{Zn}$-sulphate was significantly higher $(\mathrm{P}<0.05)$ for serum $\mathrm{Zn}$ concentration than control group. These results are in agreement with those obtained by Abou-Zeina et al (2009) in buffalos, Garg et al (2008) in lambs, Hayat et al (2010) in goats and Huerta et al.( 2002) in beef steers. These findings indicating highly bioavailability of $\mathrm{Zn}$ that released from Zn-Met supplementation and effective absorption via intestinal transport mechanisms. Also, Hempe and Cousins 1989 reported that Zn-Met complex is transported intact from the intestinal lumen into mucosal cells, which increasing tissue supply of $\mathrm{Zn}$ and thereby improving animal productivity. Moreover, Fadayifar et al (2012) suggests that adding 20 or $40 \mathrm{mg} \mathrm{Zn/kg} \mathrm{DM} \mathrm{to} \mathrm{a} \mathrm{barley} \mathrm{based} \mathrm{diet} \mathrm{containing} 22.47 \mathrm{mg} \mathrm{Zn/kg} \mathrm{DM}$ will increase plasma Zn concentration of lambs. Comparable results recorded by Huerta et al. (2002) who reported that heifers fed the diet with $\mathrm{Zn}-$ Meth had higher $(\mathrm{P}<0.05)$ concentration of $\mathrm{Zn}$ in serum than heifers fed the control or $\mathrm{Zn}$ SO4 supplemented diets. Contrary to this, Mandal et al. (2008) found that serum Zn levels did not differ $(\mathrm{P}>0.05)$ for steers fed zinc sulphate and zinc propionate. Similarly, Spears et al. (2004) did not find any effect of organic $\mathrm{Zn}$ supplementation on plasma Zn concentration in steers, fed.

Concerning thyroid hormones analysis, results of the present study revealed that Zn-methionine and Zn-sulphate had a positive effect on total $\mathrm{T}_{3}$ which was significantly elevated due to those supplements, meanwhile, the mean concentration of total T4 kept unchanged significantly due to the tested rations (G2 \&G3) based on control one (G1) (Table 3). These results are in agreement with other studies which denoting that Zn supplementation increased total T3 (Abou-Zeina et al., 2009 and Hayat et al 2010). In addition to its participation in protein synthesis, $\mathrm{Zn}$ is essential for proper thyroid function. It is involved in T3 binding to its nuclear receptor (Liu et al 2001). Also, Zn participates in synthesis and action of thyrotropin-releasing hormone (TRH). Based on these results, it is clear that there are correlations between the level of serum zinc and plasma T3 and T4 levels (Nishi et al., 1980; Aihara et al., 1984). Similar results observed by EI-Sisy et al. (2008) who reported that the total $\mathrm{T}_{3}$ was significantly increased in bucks fed diets supplemented with zinc yeast as compared with the control one. While the mean concentration of total T4 kept constant through the course of the study. Kececi and Keskin (2002) reported that lambs and goats in the $\mathrm{Zn}$ groups (40 mg/kg DM for lambs and $35 \mathrm{mg} / \mathrm{kg}$ DM for goats) had significantly higher $(\mathrm{P}<0.05)$ in plasma $\mathrm{Zn}$ values than the control one. Contrary to the above results Mandal et al. (2008) indicated that supplemental zinc either from inorganic or organic sources did not influence plasma T3 and T4 concentration in crossbred calves.

\section{Calves performance}

Results presented in (Table 4) showed that the body weight gain and daily gain were significantly higher for claves fed supplemented Zn-methionine or zinc sulphate ration than those fed control one. The body weight gain in Zn-methionine group was higher by about $35.29 \%$ and $16.59 \%$ than those fed with control and zinc sulphate respectively. It was expected that Zn-methionine supplementation had 


\section{Hassan et al.}

improved ADG due to increasing methionine absorption and stimulating activities of enzymes involved in nutrients digestibility, feeding value and feed efficiency (Tables 2, 4). Also, this study supports the concept that organic $\mathrm{Zn}$ may be metabolized differently from inorganic $\mathrm{Zn}$ and, thus, may alter some metabolic processes differently (Spears, 1996). These results are in agreement with those reported by Garg et al. (2008) and Puchala et al. (1999) who found that the average gain and feed efficiency were higher in lambs consuming a diet supplemented with $20 \mathrm{mg} \mathrm{Zn/} \mathrm{kg} \mathrm{DM} \mathrm{as} \mathrm{Zn-methionine} \mathrm{than} \mathrm{those} \mathrm{fed}$ that free from organic zinc control. Similarly, Ward et al (2002) observed greater weight gains for animals that ingested zinc in the organic form. Spears and Kegley (2002) also reported higher weaning weights for calves supplemented with organic zinc when compared with control groups that received zinc oxides or sulfates. Also, Kegley and Silzeli (1999) reported that the weight gain was improved in calves supplemented with $\mathrm{Zn}$ to a basal diet containing $21 \mathrm{mg} \mathrm{Zn} \mathrm{per} \mathrm{kg}$ diet. Such results are in contrast to those of Wright and Spears (2004) who reported similar growth performance in calves supplemented with $20 \mathrm{mg} \mathrm{Zn}$ either as Zn sulphate or Zn proteinate to a basal diet having $28 \mathrm{mg} \mathrm{Zn} / \mathrm{kg}$ DM. Similarly, Shinde et al. (2006) also did not observe any difference in the growth rate in the guinea pigs supplemented by $\mathrm{Zn}$ either through organic or inorganic sources.

Concerning DM intake Supplementation of $30 \mathrm{mg} \mathrm{Zn/head/} \mathrm{day} \mathrm{either} \mathrm{as} \mathrm{ZnSO4} \mathrm{or} \mathrm{Zn-meth} \mathrm{had} \mathrm{no}$ effect on total DMI of calves as it was comparable with control group that free from these supplements. (Table 4). These results are in agreement with those reported by Khan (1978) who did not find any effect on DMI in growing calves, when level of Zn was increased from 26.02 to $85.67 \mathrm{mg} / \mathrm{kg}$ DM in their diet. Similarly, supplementation of Zn-methionine to a basal diet (containing more than $25 \mathrm{mg} \mathrm{Zn/kg} \mathrm{DM}$ ) had no effect on feed intake in ewes (Salama Ahmed et al., 2003), growing lambs (Fadayifar et al., 2012), beef steers (Malcolm-Callis et al., 2000), bulls (Mandal et al., 2007) and Cashmere goats (Wenbin et al., 2008). These results indicate that normal dietary $\mathrm{Zn}$ concentrations either $\mathrm{ZnSO} 4$ or $\mathrm{Zn}$-meth forms do not influence DMI, but higher concentrations may have a negative influence on diet palatability (Malcolm-Callis et al., 2000). Dietary levels of $\mathrm{Zn}$ in the current experiment were within normal ranges and would not affect diet palatability.

Table (4): Growth Performance of buffalo calves fed different sources of zinc.

\begin{tabular}{|c|c|c|c|c|}
\hline Item & $\begin{array}{c}\text { Control } \\
\text { (G1) }\end{array}$ & $\begin{array}{c}\mathrm{ZnSO} 4 \\
(\mathrm{G} 2)\end{array}$ & $\begin{array}{c}\text { Zn-meth } \\
\text { (G3) }\end{array}$ & $\mathrm{P}$ \\
\hline Initial weight $(\mathrm{kg})$ & $257.50 \pm 27.53$ & $257.00 \pm 29.14$ & $258.50 \pm 22.55$ & 0.999 \\
\hline Final weight (kg) & $351.50 \pm 26.60$ & $365.50 \pm 30.88$ & $385.00 \pm 23.63$ & 0.686 \\
\hline $\mathrm{BW}$ gain $(\mathrm{kg})$ & $94.00^{c} \pm 3.01$ & $108.50^{\mathrm{b}} \pm 2.22$ & $126.50^{\mathrm{a}} \pm 2.90$ & 0.0001 \\
\hline Daily gain $(\mathrm{kg})$ & $0.783^{c} \pm 0.18$ & $0.904^{\mathrm{b}} \pm 0.16$ & $1.054^{\mathrm{a}} \pm 0.05$ & 0.0001 \\
\hline \multicolumn{5}{|l|}{ Feed Intake (FI, kg/day) } \\
\hline DMI of concentrate & $5.78 \pm 0.086$ & $5.83 \pm 0.081$ & $5.83 \pm 0.081$ & 0.951 \\
\hline DMI of wheat straw & $2.20 \pm 0.029$ & $2.19 \pm 0.028$ & $2.19 \pm 0.026$ & 0.982 \\
\hline DMI of alfalfa & $1.50 \pm 0.000$ & $1.50 \pm 0.000$ & $1.50 \pm 0.000$ & 1.000 \\
\hline Total DM intake & $9.50 \pm 0.100$ & $9.52 \pm 0.081$ & $9.53 \pm 0.081$ & 0.965 \\
\hline Feed conversion ratio kg/kg gain) & $12.19^{\mathrm{a}} \pm 0.13$ & $10.53^{b} \pm 0.09$ & $9.07^{\mathrm{c}} \pm 0.085$ & 0.0001 \\
\hline Feed cost/day E.P.* & $21.46^{\mathrm{c}} \pm 0.23$ & $22.09^{b} \pm 0.19$ & $22.87^{\mathrm{a}} \pm 0.21$ & 0.0001 \\
\hline Feed cost $/ \mathrm{kg} \mathrm{WG}^{* *}$ & $27.55^{\mathrm{a}} \pm 0.29$ & $24.43^{b} \pm 0.21$ & $21.78^{\mathrm{c}} \pm 0.20$ & 0.0001 \\
\hline
\end{tabular}

Regarding feed conversion ration data presented in Table (4) showed that supplementation of Zn-meth significantly $(\mathrm{P}<0.05)$ improved feed conversion efficiency in comparison of control ration that have no supplement. Also, similar improvement due to $\mathrm{Zn}-\mathrm{So} 4$ supplement was observed respecting FCR, compared with control diet these results are in agreement with those reported by Puchala et al. (1999) who found that higher daily gain and feed conversion efficiency of Zn-Met supplemented ration for lambs as compared to the control one that have nothing supplement . Contrary to it, Shinde et al. (2006) did not find any difference in feed efficiency in supplemented $\mathrm{Zn}$ either through organic or inorganic sources to ration of guinea pigs. Similar observations were made in calves (Engle et al., 1997; Mandal et $a l .$, 2007) and steers (Spears et al., 1991) who showed that Zn supplementation had no effect on feed efficiency with these animals. 
In spite of the higher value for feed cost/day, for calves fed supplemented $\mathrm{Zn}$-meth or $\mathrm{ZnSO} 4$ as compared with control group (Table 4), the value of feed cost/kg weight gain was lower in $\mathrm{Zn}$-meth or ZnSO4 groups as compared with control. This may be due to the improvement in weight gain for these groups as compared with control.

\section{CONCLUSION}

On the basis of the present experiment, it may be concluded that supplementation of $30 \mathrm{mg}$ $\mathrm{Zn} / \mathrm{head} /$ day as $\mathrm{Zn}$-methionine or $\mathrm{Zn}$ sulphate in addition of that naturally containing in the basal diet (containing $28.3 \mathrm{mg} \mathrm{Zn} / \mathrm{kg} \mathrm{DM}$ ) of growing buffalo calves significantly improved all nutrients digestibility and some blood metabolites as increasing $\mathrm{T}_{3}$ and decreasing concentration of total cholesterol. Also improvement in daily gain and feed conversion ratio were noticed in calves fed diet with $\mathrm{Zn}$ in $\mathrm{Zn}$-methionine group compared to $\mathrm{ZnSO} 4$ and control groups. So it could be recommended that to being supplement $\mathrm{Zn}$-methionine to growing buffaloes calves rations under Egyptian condition because of its higher bioavailability than $\mathrm{Zn}$ sulphate.

\section{REFERENCES}

Abou-Zeina, H. A. A., S. G. Hassan, H. A. Sabra and A.M. Hamam (2009). Trials for elevating adverse effect of heat stress in Buffaloes with emphasis on metabolic status and fertility. Global Veterinaria, 3(1): 51-62.

Aihara, K., Y. Nishi, S. Hatano, M. Kihara, K. Yoshimitsu, N. Ho. T. Takeichi, H. Ezaki, and T. Usui, (1984). Zinc, copper, manganese and selenium metabolism in thyroid disease. Am. J. Clin. Nutr. 40: 26-35.

AOAC, Association of Official Analytical Chemists (2000). Official Methods of Analysis, 16th ed.: AOAC. AOAC, Gaithersburg, MD, USA.

Bhandarkar S.D., and M. I. A. Pillai (1982). Radioimmunoassay: A Laboratory Manual. Bhabha Atomic Research Centre, Trombay, Bombay (India)

Cao, J., P. R. Henry, R. Guo, R. A. Holwerda, J. P. Troth, R.C. Littell, R. D. Miles and C. B. Ammerman (2000). Chemical characteristics and relative bioavailability of supplemental organic zinc sources for poultry and ruminants. J. Anim. Sci., 78: 2039-2054.

Chester J. K. (1997). Zinc In: B.L. O’Dell, R. Sunde (Editors). Handbook of Nutritionally Essential Mineral Elements. Marcel Dekker Inc., New York, pp. 185

Corah, L.R. and D. Dargatz (1996). Forage analyses from cow/calf herds in 18 states. Beef Cow/Calf Health and Productivity Audit (CHAPA). USDA Animal and Plant Health Inspection Services, National Health Monitoring System

Daghash, H.A., and S. M. Mousa (1999). Zinc sulfate supplementation to ruminant rations and its effects on digestibility in lamb; growth, rectal temperature and some blood constituents in buffalo calves under heat stress. Assiut Vet. Med. J. 40: 128-146.

Dean, C. E., B. M. Hargis, and P. S. Hargis (1991). Effects of zinc toxicity on thyroid function and histology in broiler chicks . Toxicology Letters 57: 309-318.

EI-Sisy, G. A, A. M. A. Abdel-Razek, A. A. Younis, A. M. Ghallab and M. S. S. Abdou (2008). Effect of Dietary Zinc or Selenium Supplementation on Some Reproductive Hormone Levels in Male Baladi Goats. Global Veterinaria 2 (2): 46-50.

El-Fouly, M. M., A.F.A Fawzi, AH. Fergany and F.K. El-Baz, (1984). Micronutrient staus in crop in selected area in Egypt. Commune. Soil. Sci. Plant. Anal., 15: 1175-1189.

Engle, T. E., C.F. Nockels, K. L. Hossener, C.V. Kimberling, R.E Toombs, R.S. Yemm, D.L. Weaber, and A.B. Johnson (1997). Marginal zinc deficiency affects biochemical and physiological parameters in beef heifer calves. Asian Aust. J. Anim. Sci. 10: 471-477. 


\section{Hassan et al.}

Fadayifar, A. , H. Aliarabi „, M. M. Tabatabaei , P. Zamani , A. Bahari, M. Malecki , A. H. Dezfoulian (2012). Improvement in lamb performance on barley based diet supplemented with zinc. Livestock Science 144: 285-289.

Garg, A.K., V. Mudgal, and R.S. Dass (2008). Effect of organic zinc supplementation on growth, nutrient utilization and mineral profile in lambs. Animal Feed Science and Technology 144: 82-96.

Gupta, R. P., P. C. Verma, and G. Garg (1997). Effect of experimental zinc deficiency on thyroid gland in guinea pigs. Ann. Nutr. Metabol. 41: 376-381.

Guyton, M. D., C. Arthur, J. E. Hall (1991). Textbook of medical physiology Eighth Ed., PP. 831-839.

Guyton, M. D., C. Arthur, J. E. Hall (2000). Textbook of medical physiology. Tenth Ed., PP. 858-868.

Hayat H. M. E., H. M.A. Abdel Rahman and S. A. El-Wakeel (2010). Effect of Zinc-Methionine Supplementation on Reproductive Performance, Kid's Performance, Minerals Profile and Milk Quality in Early Lactating Baladi Goats. World Applied Sciences Journal 9 (3): 275-282.

Hempe, J. M., and R.J. Cousins (1989). Effect of EDTA and Zinc Methionine complex on zinc absorption by rat intestine. J. Nutr. 119: 1179-1187.

Huerta M., R.L. Kincid, J. D. Cronrach, J. Busboom, A.B. Johnson, and C.K. Swenson, (2002). Interaction of dietary zinc and growth implants on weight gain, carcass traits and zinc in tissues of growing beef steers and heifers. Anim. Feed Sci. Tech. 95, 15-32.

Kececi T., and E. Keskin (2002). Zinc supplementation decrease total thyroid hormone concentration in small ruminants. Acta Vet. Hung. 50: 93-100.

Kegley B., and S. Silzeli (1999). The immune response and performance of calves supplemented with zinc from an organic and an inorganic source. Res. Ser. Arkansas Agr. Exp. Sta. 460: 98-101

Khan, S.A. (1978). Interaction of copper and zinc and its influence on the metabolism of major nutrients in growing calves. Ph.D Thesis. Aligarh Muslim University, Aligarh.

Lardy, G., M.S. Kerley, and J.A. Patterson (1992). Retention of metal proteinates by lambs. J. Anim. Sci. 70 (Suppl.1): 314.

Liu, N., L. Pingsheng, X. Qing Z. Li, Z. Zhiying, W. Zhengzhou, L. Yanfen, F. Wejing and Z. Lianzhen, (2001). Elements in erythrocytes of population. Trace Element Res., 84: 37-43.

Malcolm-Callis, K.J., G.C. Duff, S.A. Gunter, E.B. Kegley, and D.A. Vermeire (2000). Effects of supplemental zinc concentration and source on performance, carcass characteristics and serum values in finishing beef steers. J. Anim. Sci. 78: 2801-2808.

Mandal G.P., R.S. Dass,, A.K. Garg, V.P. Varshney and A.B. Mondal (2008). Effect of zinc supplementation from inorganic and organic sources on growth and blood biochemical profile in crossbred calves. Journal of Animal and Feed Sciences, 17, 147-156.

Mandal, G.P., R. S. Dass, D.P. Isore, A. K. Garg, and G.C. Ram (2007). Effect of zinc supplementation from two sources on growth, nutrient utilization and immune response in male crossbred cattle (Bos indicus $\times$ Bos taurus) bulls. Anim. Feed Sci. Technol. 138: 1-12.

McDowell, L. R. (1992). Zinc. In: Cunha, T. J. (ed.) Minerals in Animal and Human Nutrition. Academic Press Inc., San Diego, pp. 265-293.

Mirosław G., M. Czauderna, A. Baranowski, N. Strzałkowska, A.R Jóźwik1, and J. Krzyżewski (2007). The effect of diet supplementation with Se, Zn and vitamin E on cholesterol, CLA and fatty acid contents of meat and liver of lambs. Animal Science Papers and Reports, 25(1): 25-33.

Miyamoto, T., A. Sakurai, and L. J. Degroot (1991). Effects of zinc and other divalent metals on deoxyribonucleic acid binding and hormone binding activity of human alpha-1 thyroid hormone receptor expressed in Escherichia coli. Endocrinology 129: 3027-3033.

National Research Council (1984). Nutrient requirements of beef cattle. 6th ed. Natl. Acad. Press, Washing-ton, D.C.

National Research Council (1985). Nutrient Requirements of Domestic Animals. National Academic Press, 6th ed., Washington, D.C. 
National Research Council (2001). Nutrient requirements of Dairy Animals, 7th ed. National Academy Press, Washington, DC.

National Research Council (2000).Update Nutrient requirements of beef cattle. Seventh. Washington, DC: National Academy of Sciences.

Nishi, Y., R. Kawate, and T. Usui (1980). Zinc metabolism in thyroid disease. Postgrad . Med. J. 56: 833-837.

Nishiyama, S., Y. Futagoishi-Suginohara, M. Matsukura, T. Nakamura, A. Higashi, M. Shinohara, and I. Matsuda (1994). Zinc supplementation alters thyroid hormone metabolism in disabled patients with zinc deficiency. J. Am. College Nutr. 13: 62-67.

Perrin, P. K., D. L. Winkrnaun, E. R. Moscandi, and J. R. Anderson (1979). From organic data to farmer recommendation. An Economic Training Manual Information Bulletin. 27, Mexico.

Power R., K. Cashman, and A. Flynn. (1994). Tissue deposition of zinc for a zinc chelate and from inorganic zinc in rats. Alltech, Inc. Nicholasville, KY.

Puchala, R., T. Sahlu and I. I. Davis (1999). Effect of zinc-methionine on performance of Angora goats. Small Ruminant Res., 33: 1-8.

Ruz, M., J. Codoceo, J. Galgani, , L. Munoz, N. Gras, S. Muzzo, L. Leiva, and C. Bosco (1999). Single and multiple selenium-zinc-iodine deficiencies affect rat thyroid metabolism and ultrastructure . J. Nutr. 129: 174-180.

Salama, A. A., G. Cajat, E. Albanell, X. Snch, and R. Casals (2003). Effects of dietary supplements of zinc-methionine on milk production, udder health and zinc metabolism in dairy goats. J. Dairy Res. 70: 9-17.

SAS (2001). Statview for Windows, Version 8.2. SAS Institute, Cary, NC, USA.

Shinde, A.K., S.K. Sankhyan, R. Meena and R. K. Regar (2013). Effect of feed supplementation with copper- and zinc salts on the growth, wool yield, nutrient utilization, blood constituents and mineral profile of Malpura lambs. Agricultural Science Research Journal 3(9): pp. 284- 291.

Shinde, P., R.S. Dass, A. K Garg, , V.K. Chaturvedi, and R. Kumar (2006). Effect of zinc supplementation from different sources on growth, nutrient digestibility, blood metabolic profile and immune response of male guinea pigs . Biol. Trace Elem. Res. 112: 247-262.

Spears J.W. (1989). Zinc methionine for ruminants: Relative bioavailability of zinc in lambs and effect on growth and performance of growing heifers. J. Anim. Sci. 67, 835-843.

Spears J.W., P. Schegel, M.C. Seal, and K.E. Lloyd (2004). Bioavailability of zinc from zinc sulphate and different zinc sources and their effects on ruminal volatile fatty acid proportions. Livest. Prod. Sci. 90: 211-217

Spears, J. W. (1996). Organic trace minerals in ruminant nutrition. Anim. Feed Sci. Technol. 58:151163.

Spears, J. W., R.W. Harvey, and T. T. Brown JR (1991). Effects of zinc methionine and zinc oxide on performance, blood characteristics, and antibody titer response to viral vaccination in stressed feeder calves. J. Am. Vet. Med. Assoc. 199: 1731-1733.

Spears, J.W., and E. B. Kegley (2002). Effect of zinc source (zinc oxide vs. zinc proteinate) and level on performance, carcass characteristics, and immune response of growing and finishing steers. J. Anim. Sci. 80: 2747-2752.

Steel, R. G. and J. H. Torrie (1980). "principles and Procedures of Statistics". A Biometrical Approach (2 nd Ed) Mc Grow- Hill Book Co., New York.

Vasconcelos, J. T., and M. L. Galyean (2007). Nutritional recommendations of feedlot consulting nutritionists: The 2007 Texas Tech University survey. Journal of Animal Science 2007 85: 10: 27722781 doi:10.2527/jas.2007-0261

WARD, J. D., J. W. SPEARS and E.B. KEGLEY (2002). Effect of trace animal source on mineral metabolism, performance, and immune response in stressed cattle. Journal Animal Science, v.80: p.300, Suppl.1 


\title{
Hassan et al.
}

Wenbin, J., J. Zhihai, W. Wei, Z., Runlian, Z. Shiwei, and Z. Xiaoping, (2008). Effects of dietary zinc on performance, nutrient digestibility and plasma zinc status in Cashmere goats. Small Rum. Res. 80: 68-72.

Wright, C.L., and J.W. Spears (2004). Effect of zinc source and dietary level on zinc metabolism in Holstein calves. J. Dairy Sci. 87: 1085-1091.

تاثير اضافة الزنك من مصادر غير عضوية وعضوية على هضم المكونات الغذائية وخصائص الام واداء النمو لعجول الجاموس النامية

\author{
إكر امى حامد صادق حسن 1 و محسن تحمد فرغلى ${ }^{2}$ و جمال محمود سلومة3 \\ لهسم الإتتاج الحيوانسي وكلية الزراعة , جامعة الأزهر , فرع أسبيوط , مصر.

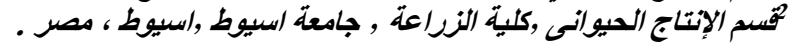

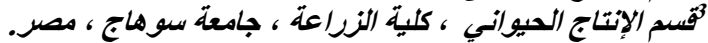

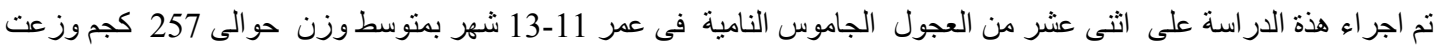

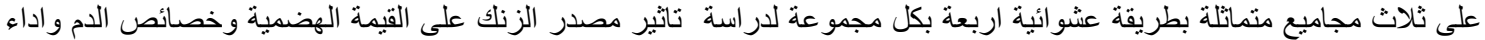

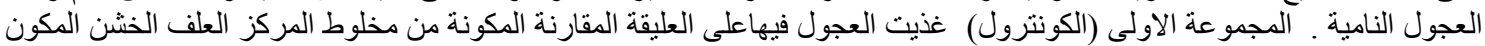

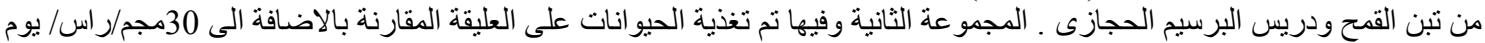

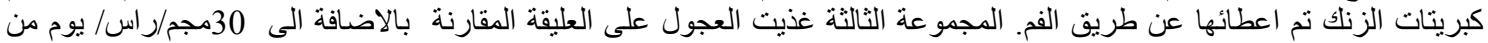

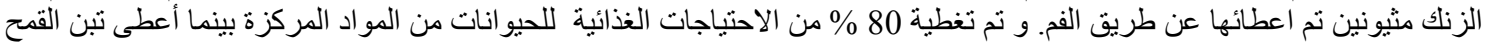

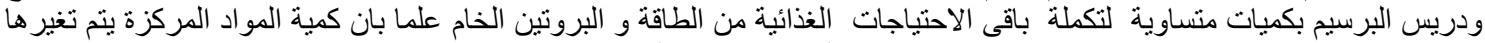

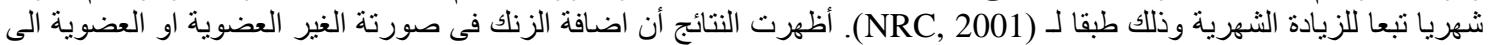

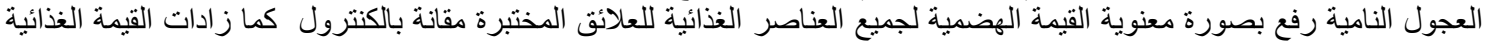

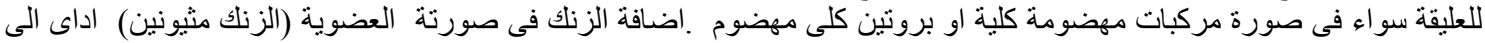

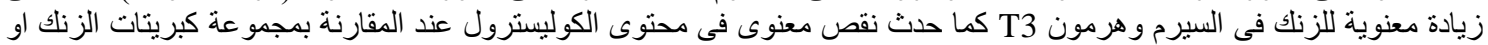

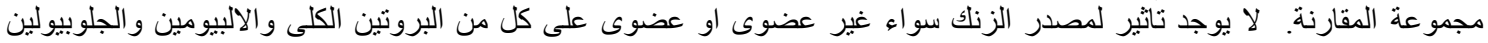

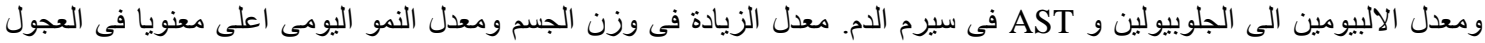

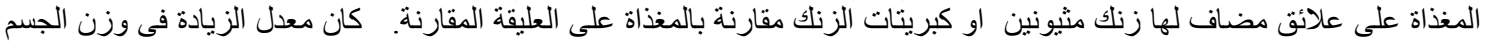

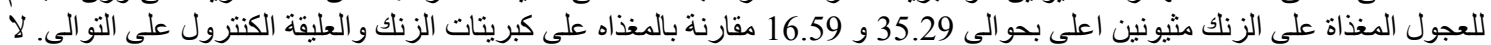

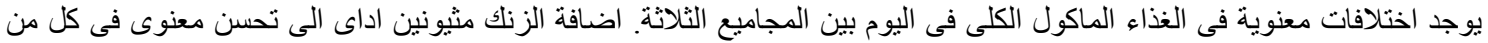

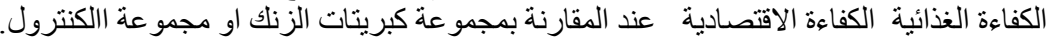

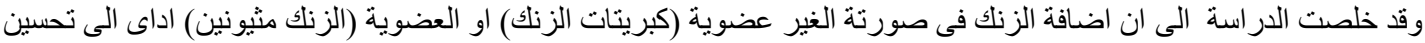

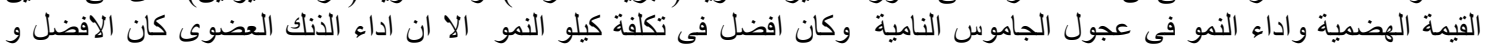

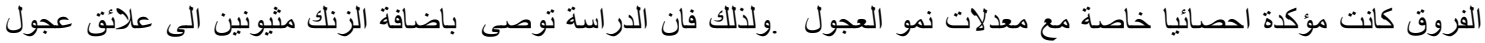

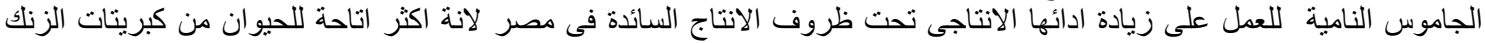

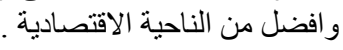

